\title{
Critical Diagnoses in Ophthalmic Pathology: Suspected Important Unanticipated Diagnoses in Surgically Removed Eyes
}

\author{
Curtis E. Margo \\ Morsani College of Medicine, University of South Florida, Department of Ophthalmology, Pathology and Cell \\ Biology, Tampa, FL, USA
}

\section{Keywords}

Alert diagnosis - Anatomic critical diagnoses · Critical values · Ocular pathology · Surgical pathology

\begin{abstract}
Aim: To describe the 5-year profile of anatomic critical diagnoses from an ophthalmic pathology laboratory and raise awareness of the challenges of establishing guidelines for these diagnoses. Methods: Medical records of patients who had consecutively submitted surgically removed globes or eviscerated eyes from 1 October 2009 to 31 October 2014 were examined for a critical diagnosis, as defined by a verbal communication for a serious, unanticipated diagnosis. Important discordant anatomic and clinical diagnoses were reviewed to determine whether the anatomic finding was truly unanticipated. Results: During the study period, 313 eyes were submitted to the laboratory as primary specimens. Twenty (6.4\%) had critical (alert) diagnoses. Six of the 20 anatomic diagnoses (30\%) were known or suspected prior to surgery but were not communicated on the pathology request form. Five diagnoses (25\%) were not clinically suspect before surgery. In 9 cases (45\%) medical-care providers were alerted to the critical findings but insufficient clinical information was provided about preoperative conditions. Conclusions: The proportion of critical diagnoses among surgically removed eyes is small, but not inconsequential. Some "critical alerts" would be unnecessary if relevant clinical in-
\end{abstract}

formation was provided when the tissue is submitted to the laboratory. Laboratory guidelines for critical values in surgical pathology should be flexible since they need to anticipate the vicissitudes of clinical practice. Surgeons need to appreciate that relevant clinical information must be provided to pathologists because it can play a role in formulating anatomic diagnoses.

(c) 2019 S. Karger AG, Basel

\section{Introduction}

The concept of critical diagnoses in surgical pathology has evolved from the practice of reporting critical laboratory values that are judged to be life-threatening [1]. Critical values in the clinical laboratory (also referred to as panic-values or alert values) differ in important ways from critical diagnoses in surgical pathology. The subject of critical diagnoses in anatomic pathology and cytopathology is confounded by the fact that tissue diagnoses are rarely, if ever, life-threatening within minutes or hours. However, there is general agreement that some diagnoses, particularly if serious and unanticipated, merit an expedited communication to the surgeon. Since 2006, the Commission on Laboratory Accreditation in anatomic pathology has mandated a policy regarding the timely communication of significant or unexpected findings [2].

\section{KARGER}

(c) 2019 S. Karger AG, Basel

E-Mail karger@karger.com

www.karger.com/oop
Curtis E. Margo, MD, MPH

Department of Pathology and Cell Biology, Morsani College of Medicine 12901 Bruce B Downs Blvd., MDC Box 79

Tampa, FL (USA)

E-Mail cmargo@ health.usf.edu 
A consensus statement on the effective communication of urgent diagnoses and significant, unexpected diagnoses in surgical pathology was published in 2012 [3]. Following a comprehensive literature search and review by an expert panel, the following conclusions emerged: (1) that each institution should create its own policy regarding urgent diagnoses and significant, unexpected diagnoses; (2) that policies about anatomic critical diagnoses should be separate from panic-values in laboratory medicine; and (3) that, while an urgent and significant unexpected anatomic diagnosis should be addressed as expeditiously as possible, the time frame should not be the same as a laboratory panic-value. The literature on critical diagnoses has focused largely on conceptual issues. A few studies have examined the application of reporting discordant clinical and anatomic diagnoses [46]. There has been no discussion about critical diagnoses in ophthalmic pathology. Ocular pathology laboratories, which often receive specimens from remote locations, differ in substantial ways from anatomic pathology laboratories in hospitals. Some differences include the inaccessibility of patient medical records and the inability to efficiently contact medical-care providers at distant locations.

To get a better understanding of what constitutes critical diagnoses in ophthalmic pathology and the frequency of such occurrences, a 5-year experience with these cases was reviewed for surgically removed eyes. For the purpose of this discussion, the term "critical anatomic diagnosis" is synonymous with an important, unanticipated diagnosis triggering a timely verbal communication between pathologist and surgeon or surrogate medical provider.

\section{Methods}

The study was limited to eviscerated or enucleated eyes submitted in formalin and accompanied by a laboratory request form in the period from 1 October 2009 to 31 October 2014. Eyes grossed and examined at other laboratories and then sent for a second opinion were excluded. Also excluded were corneal buttons, vitreous biopsies, and other ocular and periocular tissues from the eyelid, orbit, and lacrimal gland. The university pathology laboratory in this study is physically and administratively separate from any hospital or surgery center. At the time of the study it had no system of electronic medical records. All eyes were delivered by courier or the US postal system. The laboratory's only access to medical records other than the submitted pathology request form was by telephone communication or fax transmission.

Pathology reports, log records, and notes were reviewed for cases that satisfied the inclusion criteria, looking for evidence of the operational definition of critical diagnosis. This definition re-

Suspected Important Unanticipated

Diagnoses in Surgically Removed Eyes quired telephone contact between the pathologist and the surgeon, surgeon's office, or designated staff, so as to be able to notify them of a potentially important unrecognized diagnosis within 2 days of the date of the final microscopic diagnosis. Final pathology reports were typically printed as a hard copy and then faxed to the referring surgery center or hospital pathology laboratory on the day they were completed. When a surgeon's name was included in the referral request, a copy would be faxed to that individual as well. Hard copies were mailed by the US postal system no later than the next working day. Cases that met inclusion criteria were sequentially coded. No personal identifiers were abstracted from clinical records.

\section{Results}

A total of 313 eyes that met the inclusion criteria were submitted to the laboratory during the study period. Twenty (6.4\%) had potentially important unanticipated diagnoses that prompted telephone communication with the surgeon or principal eye care provider. All clinical information submitted to the laboratory, except for age, gender, and laterality of the eye, is listed in column 2 of Table 1 . All but 1 case (sympathetic ophthalmia) fell into 4 "alert" categories: (1) a potentially unrecognized extrascleral extension of an uveal melanoma; (2) a possible unrecognized intraocular tumor; (3) a potentially unrecognized intraocular infection; and (4) a potentially important associated systemic medical condition (Table 1).

The single most common finding requiring verbal communication was extrascleral extension of an uveal melanoma in 6 eyes (Case Nos. 5, 13, 16, 17, 18, and 19). Two of these eyes contained silicone oil (Case Nos. 5 and 16). After communicating the anatomic findings to the surgeon or office staff, no additional clinical information was made available in 5 cases. Extrascleral extension was known preoperatively for 1 patient (Case No. 19), but the operating room personnel failed to include this information on the pathology request form.

In 4 cases, intraocular tumors were found in eyes submitted as "blind" or "blind and painful." Three were uveal melanomas and 1 was a hemangioblastoma. Three of these diagnoses were known prior to enucleation. In each case, the operating room personnel failed to list the relevant clinical history on the pathology request form. One choroidal melanoma was an unanticipated diagnosis in an ischemic eye with neovascular glaucoma (Case No. 4).

Five eyes submitted as "blind" or "phthisical" had infectious endophthalmitis, 3 of which were consistent with endogenous infection. Another had fungal endophthalmitis that arose from the cornea (Case Nos. 2, 10, 12, 14, and 15). In 2 cases, the operating room personnel failed 
Table 1. Potentially important unanticipated anatomic diagnoses

\begin{tabular}{|c|c|c|c|c|}
\hline $\begin{array}{l}\text { Case } \\
\mathrm{No}^{\mathrm{a}}\end{array}$ & $\begin{array}{l}\text { Submitted } \\
\text { clinical } \\
\text { diagnosis }^{\mathrm{b}}\end{array}$ & $\begin{array}{l}\text { Potentially important } \\
\text { unanticipated anatomic } \\
\text { diagnosis }\end{array}$ & $\begin{array}{l}\text { Eventually established } \\
\text { preoperative clinical } \\
\text { diagnosis }\end{array}$ & Interpretation or outcome \\
\hline
\end{tabular}

\section{Potentially unanticipated intraocular tumor}

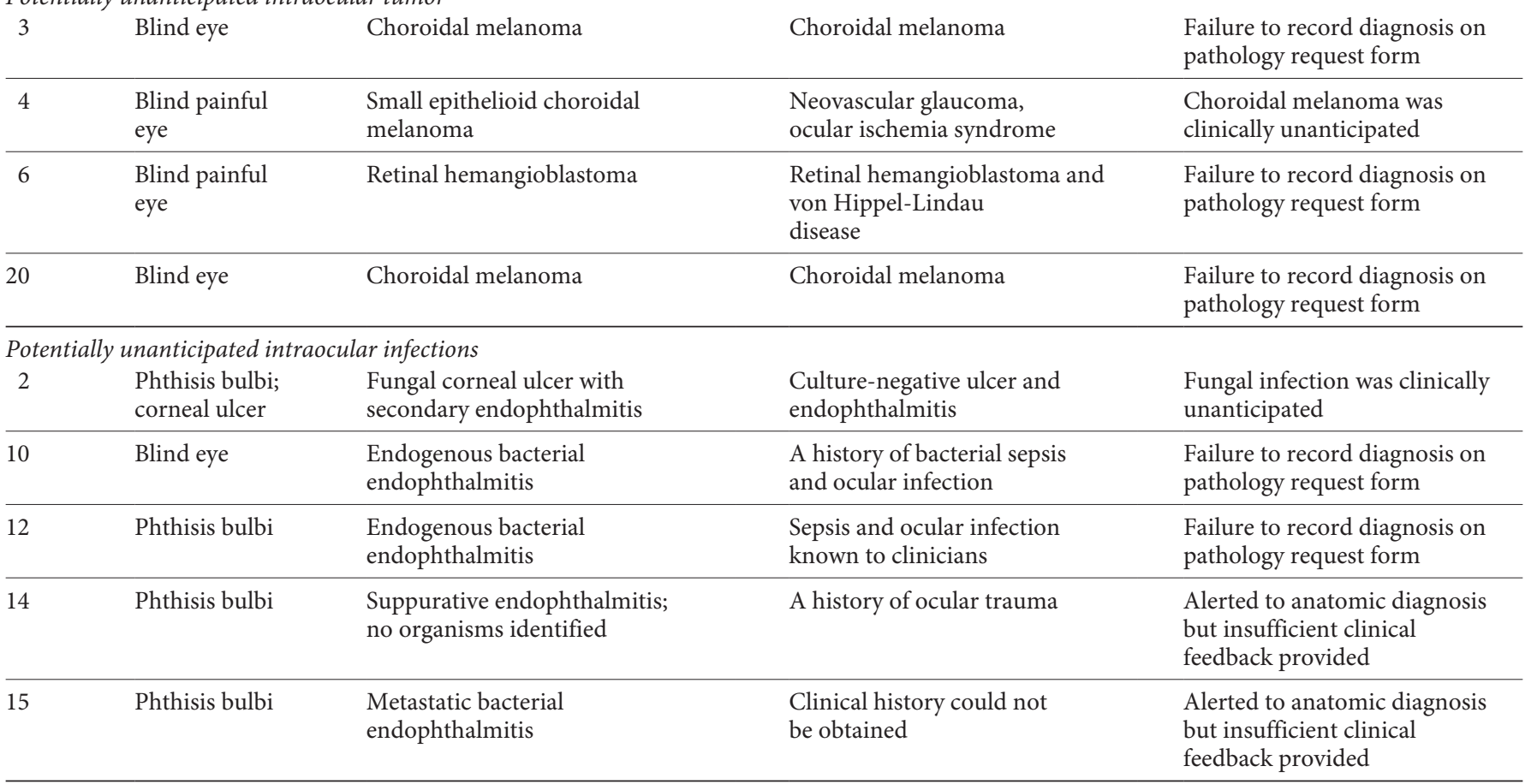

\section{Potentially unanticipated extraocular extension of uveal melanoma}

$\begin{array}{lll}\text { Melanoma } & \begin{array}{l}\text { Ciliochoroidal melanoma } \\ \text { with extraocular extension } \\ \text { and positive surgical margins }\end{array} & \begin{array}{l}\text { Choroidal melanoma; } \\ \text { brachytherapy; vitrectomy }\end{array}\end{array}$
feedback provided

\begin{tabular}{|c|c|c|c|}
\hline 13 & Melanoma & $\begin{array}{l}\text { Ciliochoroidal melanoma } \\
\text { with extraocular extension }\end{array}$ & $\begin{array}{l}\text { Clinical history could not } \\
\text { be obtained }\end{array}$ \\
\hline
\end{tabular}

\begin{tabular}{|c|c|c|c|}
\hline 16 & Melanoma & $\begin{array}{l}\text { Melanoma with extraocular } \\
\text { extension and positive } \\
\text { surgical margins }\end{array}$ & $\begin{array}{l}\text { Melanoma; brachytherapy; } \\
\text { vitectromy }\end{array}$ \\
\hline
\end{tabular}

\begin{tabular}{|c|c|c|c|}
\hline 17 & $\begin{array}{l}\text { Choroidal } \\
\text { melanoma }\end{array}$ & $\begin{array}{l}\text { Choroidal melanoma } \\
\text { with extraocular extension }\end{array}$ & $\begin{array}{l}\text { Clinical history could not } \\
\text { be obtained }\end{array}$ \\
\hline
\end{tabular}

\begin{tabular}{|c|c|c|c|}
\hline 18 & Cancer & $\begin{array}{l}\text { Choroidal melanoma } \\
\text { with extraocular extension }\end{array}$ & $\begin{array}{l}\text { Clinical history could not } \\
\text { be obtained }\end{array}$ \\
\hline
\end{tabular}

\begin{tabular}{llll}
\hline $\begin{array}{l}\text { Choroidal } \\
\text { melanoma }\end{array}$ & $\begin{array}{l}\text { Choroidal melanoma } \\
\text { with extraocular extension }\end{array}$ & $\begin{array}{l}\text { Extraocular extension } \\
\text { known preoperatively }\end{array}$ & $\begin{array}{l}\text { Failure of operating room } \\
\text { personnel to record relevant } \\
\text { diagnoses }\end{array}$ \\
\hline
\end{tabular}

\begin{tabular}{cllll}
\hline $\begin{array}{c}\text { Potentially } \\
\text { unanticipated important systemic disease associations }\end{array}$ & Blind painful eye; unilateral & Thromboembolic disease was \\
7 & Blind painful & $\begin{array}{l}\text { Neovascular glaucoma; } \\
\text { thromboembolic occlusion } \\
\text { of posterior ciliary arteries }\end{array}$ & $\begin{array}{l}\text { end-stage glaucoma } \\
\text { eye }\end{array}$ &
\end{tabular}


Table 1 (continued)

\begin{tabular}{|c|c|c|c|c|}
\hline $\begin{array}{l}\text { Case } \\
\mathrm{No}^{\mathrm{a}}\end{array}$ & $\begin{array}{l}\text { Submitted } \\
\text { clinical } \\
\text { diagnosis }^{\text {b }}\end{array}$ & $\begin{array}{l}\text { Potentially important } \\
\text { unanticipated anatomic } \\
\text { diagnosis }\end{array}$ & $\begin{array}{l}\text { Eventually established } \\
\text { preoperative clinical } \\
\text { diagnosis }\end{array}$ & Interpretation or outcome \\
\hline 9 & $\begin{array}{l}\text { Blind painful } \\
\text { eye }\end{array}$ & $\begin{array}{l}\text { Solitary annual necrotizing } \\
\text { granuloma }\end{array}$ & $\begin{array}{l}\text { Chronic unilateral uveitis; } \\
\text { presumed sarcoidosis }\end{array}$ & $\begin{array}{l}\text { Annual necrotizing granuloma } \\
\text { was clinically unanticipated }\end{array}$ \\
\hline 11 & $\begin{array}{l}\text { Blind painful } \\
\text { eye }\end{array}$ & Scleral-uveitis; necrotizing scleritis & $\begin{array}{l}\text { Cause of blind eye unknown to } \\
\text { surgeon; patient known } \\
\text { to have extra-articular } \\
\text { complications of rheumatoid } \\
\text { arthritis }\end{array}$ & $\begin{array}{l}\text { Diagnosis of systemic collagen } \\
\text { vascular disease known to } \\
\text { primary care provider and } \\
\text { rheumatologist }\end{array}$ \\
\hline \multicolumn{5}{|c|}{ Miscellaneous potentially important unanticipated clinical diagnoses } \\
\hline
\end{tabular}

to document the relevant clinical diagnoses. In 2 other cases, no clinical history could be obtained. The diagnosis of fungal endophthalmitis was unanticipated.

In 4 cases, a potentially unrecognized systemic disorder with ocular manifestations was found: thromboembolic occlusion of the posterior ciliary arteries (Case No. 7); severe choroiditis and panretinal atrophy with intense eosinophilia (Case No. 8); annular necrotizing granuloma of the ciliary body (Case No. 9) [7]; and noninfectious necrotizing scleritis (Case No. 11). In 3 cases, the diagnoses were unanticipated (Case Nos. 7, 8, and 9). The diagnosis of rheumatoid arthritis was known in the patient with necrotizing scleritis but was not conveyed on the pathology request form.

Another eye was removed because it was blind and painful; it showed sympathetic ophthalmia (Case No. 1). This diagnosis was known but was not included on the pathology request form.

\section{Discussion}

There is no universally agreed-upon definition of a critical diagnosis in surgical pathology. What qualifies as necessitating an urgent (or timely) communication, or what constitutes a significant unexpected diagnosis can vary among pathologists and among different specialists $[8,9]$. One survey of 15 anatomic pathologists and 44 nonpathologist medical personnel found a statistically significant difference in these types of judgement [8]. Nonpathologists were more likely to consider a diagnosis as "critical" than pathologists were ( 49 vs. $12 \%, p<0.001$ ).

Only a few studies have examined the application of critical values in surgical pathology practice. One survey of 5 children's hospitals found that 413 critical value reports were issued in a single year, representing $9.4 \%$ of all surgical pathology specimens [4]. This proportion of critical values is high compared to the $3.4 \%$ reported at an adult-care academic medical center [5]. The spectrum of critical diagnoses varied between these institutions, partly due to the differences in the patient populations and the type of specimens submitted to the laboratory. In a third study conducted at a general hospital, the proportion of critical values was just $0.49 \%$ [6]. This low percentage likely reflects the patient population, type of specimens, and how the institution delineated critical values.

In this study, $30 \%$ of communications $(6 / 20)$ were for cases that lacked relevant clinical information on the laboratory request form, which would have obviated the verbal communication. This problem is not unique to ophthalmic pathology. It is ubiquitous in clinical practice and a known hazard to the safety of patients [10-12]. A single institution examining $>20,000$ submitted specimens found that $8.4 \%$ of requisitions contained no clinical history [10]. In a nested review of those cases, $0.7 \%$ had an incorrect history. A major quality improvement program 
of the College of American Pathologists involving 341 laboratories revealed that the lack of clinical information was associated with a higher rate of changed anatomic diagnoses or revised reports [11]. The frustration of having to render diagnoses in the absence of clinical histories has led some pathologists to wonder (sarcastically) if their colleagues believe they possess extrasensory perception [13].

The single most common reason that triggered verbal communication in this series was the presence of an extrascleral extension of uveal melanoma. In only $1 / 6$ cases (Case No. 19), could the preoperative suspicion of extrascleral extension be confirmed. None of the diagnoses in this series would be considered time-sensitive enough that a delay of a day or two would alter management. This differs from the situation regarding clinical laboratory tests that are usually viewed as potentially lifethreatening if not addressed within hours. One reason these ocular diagnoses prompted verbal communication is the pathologist's (author's) feeling that an important anatomic diagnosis can get overlooked within a written pathology report. The inability of a substantial minority of clinicians to accurately decipher pathology reports has been documented, resulting in various attempts to standardize reports and nomenclature to improve communication $[14,15]$. An open-book examination-style study comparing clinician comprehension with pathologist intent in written pathology reports showed that surgeons misunderstood reports $30 \%$ of the time [16]. Eye pathology reports of enucleated eyes typically include a cadre of diagnoses related to cornea, lens, uveal tract, retina, vitreous, sclera, and optic nerve. Concern that a single finding like cholesterol thromboembolus in a posterior ciliary artery (Case No. 7 in this study) or multifocal subretinal abscesses (Case No. 10) might be overlooked or their clinical implications go unappreciated is what prompted direct contact with the surgeon. Further complicating the communication is the fact that the so-called referring physician listed on the surgical pathology request form can be the admitting physician (usually an internist or primary care physician) or the pathologist from the primary hospital. It was not uncommon in this study to go through several physicians before connecting with the one who was actually familiar with the patient's relevant medical history.

The quality of clinical information submitted on ophthalmic pathology request forms has not been systematically studied, but it would likely vary depending on the type of hospital or surgery center from which the specimen originated, and the surgeon's background and train- ing. This single-center ophthalmic pathology laboratory review, performed when no electronic medical records system was available to link the laboratory to a hospital or surgery center, limits the generalizability of our results. On the other hand, there were no written or prescribed guidelines for initiating anatomic critical diagnoses (alert calls) at the time of the study, which eliminated a major systematic bias. The pathologist (author) in this setting used clinical judgements when deciding if an anatomic diagnosis might be important and if it varied substantially from the clinical diagnosis. The timeliness of communication to the surgeon was a factor in deciding when to call in a diagnosis. Cases referred in the name of the pathologist only would guarantee an additional time delay, since outside pathology departments would then need to forward the report to the surgeon. The lack of a surgeon's name on a referring pathology request form thus heightened the perceived need for telephone communication. Another concern was that the pathology report might simply get overlooked because of common distractions in a busy clinical practice. Often ignored when reviewing the subject of critical diagnoses is the fact that telephone communication also provides intangible benefits to patient care for it encourages a discussion between the pathologist and surgeon on facets of the report that might need clarification or amplification.

Discordant clinical and anatomic diagnoses are longstanding, universal problems in medical practice and deserve ongoing discussion. This type of study should raise awareness of the issues involved in the debate of how to minimize miscommunication and potential clinical mishaps. Some authorities argue that verbal communication of critical values in surgical pathology is ill-conceived [17]. First, it places the pathologist in the position of second-guessing the clinician. The process can also generate ill will if the pathologist is seen as "policing" clinical practice. Second, documentation of the verbal communication in the medical records could have adverse consequences, should a case result in malpractice litigation. On the other hand, timely verbal communication can avoid a potentially overlooked anatomic diagnosis that can alter patient care.

\section{Conclusions}

The notion of critical diagnosis in surgical pathology involves a judgment of the seriousness of an anatomic finding and whether it was clinically anticipated or not. Pathologists are less likely to mistakenly deem a diagno-
Ocul Oncol Pathol 2020;6:44-49 DOI: $10.1159 / 000500640$
Margo 
sis as unanticipated if relevant clinical information accompanies the specimen to the laboratory. Since eyes removed surgically are often associated with multiple diagnoses, pathologists must keep in mind that a clinically important anatomic finding can be overlooked in a lengthy report. As long as critical (i.e., urgent alert) anatomic diagnoses are a requisite of laboratory certification, the certification guidelines should be linked with the continued education of surgeons and operating room personnel about the value of providing a relevant clinical history along with any specimen submitted to the laboratory.

\section{Statement of Ethics}

This study complied with guidelines of human research as it applies to protected health information in medical records. Only minimum necessary information was extracted from the medical records. Extracted case information without personal identifying elements were stored in password-protected files. The study was approved by the Institutional Review Board of the Morsani College of Medicine (IRB\#: CR1_Pro00020058).

\section{Disclosure Statement}

There were no conflicts of interest.

\section{References}

1 Silverman JF, Fletcher CD, Frable WJ, Goldblum JR, Pereira TC, Swanson PE; Association of Directors of Anatomic and Surgical Pathology. Critical diagnoses (critical values) in anatomic pathology. Hum Pathol. 2006 Aug;37(8):982-4.

2 College of American Pathologists Laboratory Accreditation Program. Anatomic Pathology Checklist. Northfield (IL): CAP; 2007.

3 Nakhleh RE, Myers JL, Allen TC, DeYoung BR, Fitzgibbons PL, Funkhouser WK, et al. Consensus statement on effective communication of urgent diagnoses and significant, unexpected diagnoses in surgical pathology and cytopathology from the College of American Pathologists and Association of Directors of Anatomic and Surgical Pathology. Arch Pathol Lab Med. 2012 Feb;136(2):14854.

4 Coffin CM, Spilker K, Lowichik A, Zhou H, Nielson K, Erickson L, et al. Critical values in pediatric surgical pathology: definition, implementation, and reporting in a children's hospital. Am J Clin Pathol. 2007 Dec;128(6): 1035-40.

5 Huang EC, Kuo FC, Fletcher CD, Nosé V. Critical diagnoses in surgical pathology: a ret- rospective single-institution study to monitor guidelines for communication of urgent results. Am J Surg Pathol. 2009 Jul;33(7):1098102.

6 Pereira TC, Liu Y, Silverman JF. Critical values in surgical pathology. Am J Clin Pathol. 2004 Aug; 122(2):201-5.

7 Margo C, Zimmerman LE. Idiopathic solitary granuloma of the uveal tract. Arch Ophthalmol. 1984 May;102(5):732-5.

8 Renshaw SA, Gould EW, Renshaw AA. Unexpected expectations in critical values in anatomic pathology: improving agreement between pathologists and nonpathologists with the treatable immediately, life-threatening terminology. Arch Pathol Lab Med. 2011 Nov; 135(11):1391-3.

9 Cretara $\mathrm{AD}$, Otis $\mathrm{CN}$. Perspectives and perceptions of urgent and alert values in surgical pathology and cytopathology: A survey of clinical practitioners and pathologists. Cancer Cytopathol. 2018 Dec;126(12):970-9.

10 Layfield LJ, Factor RE, Jarboe EA. Clinician compliance with laboratory regulations requiring submission of relevant clinical data: A one year retrospective analysis. Pathol Res Pract. 2012 Nov;208(11):668-71.
11 Nakhleh RE, Gephardt G, Zarbo RJ. Necessity of clinical information in surgical pathology. Arch Pathol Lab Med. 1999 Jul;123(7): 615-9.

12 Waller JM, Zedek DC. How informative are dermatopathology requisition forms completed by dermatologists? A review of the clinical information provided for 100 consecutive melanocytic lesions. J Am Acad Dermatol. 2010 Feb;62(2):257-61.

13 Bull AD, Cross SS, James DS, Silcocks PB. Do pathologists have extrasensory perception? BMJ. 1991 Dec;303(6817):1604-5.

14 Leslie KO, Rosai J. Standardization of the surgical pathology report: formats, templates, and synoptic reports. Semin Diagn Pathol. 1994 Nov;11(4):253-7.

15 Ruby SG. Clinician interpretation of pathology reports: confusion or comprehension? Arch Pathol Lab Med. 2000 Jul;124(7):943-4.

16 Powsner SM, Costa J, Homer RJ. Clinicians are from Mars and pathologists are from Venus. Arch Pathol Lab Med. 2000 Jul;124(7): 1040-6.

17 LiVolsi VA, Leung S. Communicating critical values in anatomic pathology. Arch Pathol Lab Med. 2006 May;130(5):641-4. 